\title{
PANDEMIK COVID-19 DI MALAYSIA: MENGURUS INFODEMIK MELALUI MAJLIS AKHBAR
}

\section{(COVID-19 Pandemic in Malaysia: Managing Infodemic through Press Council)}

\author{
Hafidz Hakimi Haron* \\ hafidz.haron@mmu.edu.my \\ Fakulti Undang-Undang, Universiti Multimedia \\ Mahyuddin Daud \\ mahyuddin@iium.edu.my
}

Kulliyah Undang-undang Ahmad Ibrahim, Universiti Islam Antarabangsa

Malaysia

Pengarang Koresponden (Corresponding Author): *

Rujukan artikel ini (To cite this article): Hafidz Hakimi Haron \& Mahyuddin Daud. (2021). Pandemik COVID-19 di Malaysia: mengurus infodemik melalui Majlis Akhbar. Kanun: Jurnal Undangundang Malaysia, 33(2), 239-268.http://doi.org. 10.37052/k33(2)no3

\begin{tabular}{|llllll|}
\hline $\begin{array}{l}\text { Peroleh: } \\
\text { Received: }\end{array} \quad 20 / 1 / 2021$ & $\begin{array}{l}\text { Semakan: } \\
\text { Revised }\end{array}$ & 1/5/2021 & $\begin{array}{l}\text { Terima: } \\
\text { Accepted: 20/5/2021 }\end{array}$ & $\begin{array}{l}\text { Terbit dalam talian: 6/7/2021 } \\
\text { Published online }\end{array}$ & \\
\hline
\end{tabular}

\begin{abstract}
Abstrak
Fenomena penyebaran berita palsu dalam talian dilihat semakin berleluasa ketika dunia sedang menghadapi cabaran pandemik COVID-19. Lambakan maklumat yang turut dikenali sebagai infodemik telah memberikan kesan negatif terhadap usaha untuk mengawal penularan virus COVID-19. Fenomena infodemik ini juga telah menimbulkan kegelisahan dan ketidakpercayaan terhadap usaha kerajaan bagi melawan pandemik ini dalam kalangan rakyat. Bagi mengawal infodemik, pihak berkuasa telah menguatkuasakan tindakan perundangan secara tegas, namun dilihat oleh sebahagian pengkritik sebagai tidak efektif, drakonian dan tidak demokratik. Berdasarkan latar belakang ini, kajian ini menilai semula isu-isu perundangan yang timbul dalam kerangka undang-undang antiberita palsu sedia ada di Malaysia yang menyebabkan fenomena infodemik sukar dikawal selia. Kajian ini juga mengusulkan cadangan untuk mengawal selia penyebaran berita palsu dan mengurus infodemik
\end{abstract}


melalui penubuhan Majlis Akhbar. Bagi mencapai objektif ini, kajian ini menggunakan metode kualitatif bagi mengumpulkan maklumat melalui kaedah analisis tekstual perundangan serta kaedah temu bual semi struktur.

Kata kunci: Undang-undang Perlembagaan, kebebasan bersuara, kebebasan akhbar, undang-undang media, Majlis Akhbar, infodemik

\begin{abstract}
The online dissemination offake news and disinformation phenomenon has become increasingly rampant as the world continues to face the COVID-19 pandemic. The overabundance of available information on a subject matter, known as infodemic, has negatively affected the effort to fight the pandemic. The phenomenon of infodemic has also amplified anxiety and mistrust among the people against the authorities' effort to curb the spread of COVID-19. Strict legal actions have been taken by the authorities in their crusade against the infodemic. Regardless, these actions have been construed by critics as being ineffective, draconian, and undemocratic. Thus, the main objective of this study is to re-evaluate the effectiveness of existing related laws in Malaysia that make it difficult to regulate infodemic. This study also proposes the establishment of a Press Council to curb misinformation and manage infodemic. To achieve the research objective, this study adopts a qualitative methodology in formulating its findings, which is mainly through textual analysis of legislations as well as semi-structured interviews.
\end{abstract}

Keywords: Constitutional law, freedom of speech, freedom of press, media laws, Media Council, infodemic

\title{
PENDAHULUAN
}

Pandemik COVID- $19^{1}$ yang melanda dunia pada hari ini telah membuka dimensi baharu terhadap kaedah pengawalan penyakit berjangkit. Sekiranya metode pengawalan pandemik terdahulu bergantung sepenuhnya pada kaedah pengasingan dan kuarantin, pada hari ini kita dapat lihat

1 World Health Organization. (2020). Managing the COVID-19 infodemic: Promoting healthy behaviours and mitigating the harm from misinformation and disinformation. World Health Organization. https://www.who.int/news/item/23-09-2020-managingthe-covid-19-infodemic-promoting-healthy-behaviours-and-mitigating-the-harm-frommisinformation-and-disinformation\%0Ahttps://www.who.int/news-room/detail/23-092020-managing-the-covid-19-infodemic-promotin. 
bahawa teknologi dan media sosial turut digunakan secara meluas bagi memerangi penularan COVID-19. Kemajuan teknologi maklumat yang dikecapi pada hari ini telah memudahkan pengedaran informasi berkaitan, sekali gus membantu pihak berwajib menangani penularan wabak COVID-19 secara lebih efektif. Namun demikian, kemajuan teknologi yang sama juga telah mencipta peluang untuk penyebaran informasi palsu secara lebih agresif, sekali gus mampu merencatkan usaha global untuk memerangi pandemik ini. Pada masa yang sama, tindakan tegas melalui saluran perundangan yang diambil oleh kerajaan terhadap penyebar berita palsu, terutamanya yang berkaitan dengan pandemik COVID-19 dilihat pengkritik sebagai tidak efektif, drakonian dan tidak demokratik. ${ }^{2}$ Oleh yang demikian, satu penelitian dan penilaian khusus haruslah dilakukan untuk menjamin keseimbangan antara mengurus kebanjiran maklumat palsu serta meraikan hak kebebasan bersuara seperti yang telah termaktub dalam Perlembagaan Persekutuan. ${ }^{3}$

\section{PENGERTIAN INFODEMIK}

Fenomena infodemik bukanlah sesuatu yang baharu, malahan terma ini dipercayai telahpun mula diguna pakai sejak penularan wabak SARS pada tahun 2003 yang lalu. Menurut Pertubuhan Kesihatan Sedunia (WHO), terma infodemik boleh didefinisikan sebagai gabungan perkataan "information" dan "pandemic" yang merujuk lambakan, dan seterusnya membawa kepada penyebaran maklumat benar ataupun tidak benar, secara pantas dan meluas berkaitan dengan sesuatu perkara, khususnya penyakit. ${ }^{4}$ Walaupun definisi infodemik bersifat neutral pada asasnya, namun terma ini telah diwarnai dengan konotosi negatif sekali gus menggambarkannya bersangkut paut dengan penyebaran informasi palsu berkenaan dengan penyakit atau wabak yang tertentu. Menurut Chamil Wariya, berita palsu boleh dikategorikan kepada lima jenis, iaitu: (1) secara sengaja menipu; (2) satira atau lawak yang boleh diterima sebagai benar; (3) penipuan besar-besaran; (4) keserongan dalam melaporkan

2 Harris Zainul, "Malaysia's Infodemic and Policy Response," ISIS Policy Brief, no. 2-20 (2020): 1-4, https://www.isis.org.my/wp-content/uploads/2020/06/POLICYBRIEF_MALAYSIA-INFODEMIC-AND-POLICY-RESPONSE.pdf.

3 Sila rujuk Perkara 10(1)(a) Perlembagaan Persekutuan.

4 World Health Organization, "Managing the COVID-19 Infodemic: Promoting Healthy Behaviours and Mitigating the Harm from Misinformation and Disinformation." 
fakta sebenar; dan (5) cerita yang kebenarannya menjadi perbalahan atau pertelingkahan. ${ }^{5}$

Menurut Sameera, fenomena infodemik atau lambakan maklumat ini disebabkan oleh kemudahan infrastruktur informasi moden sedia ada yang membolehkan seseorang mengakses maklumat dalam pelbagai cara. ${ }^{6}$ Menurut beliau lagi, lambakan maklumat sebegini membuatkan pengguna maklumat tidak mampu memproses maklumat tersebut dengan baik, sekali gus membuka ruang kepada kesalahfahaman terhadap maklumat tersebut. ${ }^{7}$

Menurut Pertubuhan Kesihatan Sedunia (WHO), penyebaran maklumat palsu berkaitan dengan pandemik secara tidak terkawal bukan sahaja mampu merencatkan usaha menghentikan penyebaran virus COVID-19, malah berpotensi untuk menjejaskan kesihatan fizikal dan mental, serta mampu meningkatkan stigma sosial terhadap wabak tersebut. $^{8}$ Namun begitu, pada ketika ini, respons terhadap infodemik adalah bersifat tempatan dan tidak menyeluruh walaupun masalah ini bersifat global. ${ }^{9}$ Oleh sebab kurangnya tindak balas berskala global, jaminan terhadap perlindungan hak asasi manusia berada dalam keadaan terancam. ${ }^{10}$ Pengawalseliaan dan tapisan maklumat yang berlebihan juga untuk menangani krisis ini mampu membawa kesan jangka panjang kepada sistem pendidikan, ekonomi, politik, dan juga sosial. ${ }^{11}$

Kemudahan akses terhadap maklumat juga telah menyumbang kepada fenomena infodemik khususnya di Malaysia. Menurut sebuah kajian yang dijalankan oleh Institut Reuters dan University Oxford, United Kingdom, Malaysia mempunyai capaian akses internet yang agak tinggi, iaitu sebanyak $81 \%$ daripada 32 juta rakyatnya pada tahun

5 Chamil Wariya. (2017). Krisis dan strategi : Cabaran kewartawanan dan media era digital. Malaysian Press Institute, 124.

6 Sameera Tahira Ahmed. (2020). Managing News Overload (MNO): The COVID-19 Infodemic. Information (Switzerland), 11(8). https://doi.org/10.3390/INFO11080375.

7 Ahmed (2020).

8 World Health Organization, "Managing the COVID-19 Infodemic: Promoting Healthy Behaviours and Mitigating the Harm from Misinformation and Disinformation."

9 Roxana Radu. (2020). Fighting the 'infodemic': Legal responses to COVID-19 disinformation. Social Media and Society, 6(3) https://doi.org/10.1177/2056305120948190

10 Radu (2020).

11 Radu (2020). 
2020.12 Dalam masa yang sama, 86\% pengguna internet di Malaysia memilih media sosial sebagai sumber berita yang utama. Kajian yang sama turut mendapati bahawa 57\% pengguna aplikasi Facebook, dan $51 \%$ pengguna aplikasi Whatsapp menggunakan aplikasi tersebut bagi tujuan mendapatkan informasi dan berita. ${ }^{13}$ Satu lagi kajian mengatakan bahawa, tidak kurang $64 \%$ pengguna bergantung pada media atas talian sebagai sumber asas untuk maklumat berkaitan dengan pandemik COVID-19. ${ }^{14}$ Data daripada kajian Institut Reuters juga menunjukkan bahawa kebergantungan terhadap media cetak secara umumnya telah menurun dengan drastik, iaitu daripada 45\% pada tahun 2017, kepada hanya $30 \%$ pada 2020 . Penulis berpendapat bahawa, dapatan daripada data kajian ini adalah cukup menggusarkan. Hal ini kerana kurangnya elemen pengesahan terhadap maklumat yang diterbitkan di media sosial jika dibandingkan dengan media tradisional sedia ada, sekali gus menggalakkan penularan berita palsu.

Lebih membimbangkan lagi, kebergantungan terhadap sumber informasi dalam talian tidak terhad kepada pengguna biasa, malahan turut membabitkan pengamal media arus perdana. Kajian terkini oleh Von Nordheim, Boczek dan Koppers mengatakan bahawa terdapat pertambahan penggunaan kandungan dalam talian yang signifikan dalam kalangan wartawan di seluruh dunia, dan semakin menjadi norma baharu dalam kewartawanan moden. ${ }^{15}$ Tindakan menerbitkan semula maklumat dalam talian yang tidak disahkan secukupnya merupakan satu kesalahan yang besar dalam dunia kewartawanan dan bercanggah dengan Kod Etika Kewartawanan. Tindakan menerbitkan semula maklumat yang tidak sahih boleh ditafsirkan sebagai suatu yang sah (validasi) oleh masyarakat umum daripada pihak media berautoriti, sekali gus memburukkan lagi masalah berita palsu dan infodemik.

12 Nic Newman et al. (2020). Reuters Institute Digital News Report 2020. https:// reutersinstitute.politics.ox.ac.uk/sites/default/files/2020-06/DNR_2020_FINAL.pdf.

13 Newman et al.

14 Emma Mohamad et al. (2020). Relationship between COVID-19 information sources and attitudes in battling the pandemic among the Malaysian public: Cross-sectional survey study. Journal of Medical Internet Research, 22(11), 1-13, https://doi.org/10.2196/23922.

15 Gerret von Nordheim, Karin Boczek, and Lars Koppers, "Sourcing the Sources: An Analysis of the Use of Twitter and Facebook as a Journalistic Source over 10 Years in The New York Times, The Guardian, and Süddeutsche Zeitung," Digital Journalism 6, no. 7 (2018): 807-28, https://doi.org/10.1080/21670811.2018.1490658. 


\section{HAK KEBEBASAN BERSUARA MENURUT INSTRUMEN PERUNDANGAN ANTARABANGSA DAN PERLEMBAGAAN PERSEKUTUAN}

Secara asasnya jaminan terhadap hak kebebasan bersuara adalah bersifat universal. Terdapat dua instrumen perundangan antarabangsa utama tentang hak asasi manusia, iaitu Perisytiharan Hak Asasi Manusia Sejagat (Universal Declaration of Human Rights (UDHR)) dan juga Perjanjian Antarabangsa Mengenai Hak-hak Sivil dan Politikal (International Covenant on Civil and Political Rights (ICCPR)). Perkara 19 UDHR menggariskan bahawa kebebasan bersuara merangkumi "kebebasan berpendapat dan juga kebebasan mengeluarkan fikiran". Kebebasan ini secara amnya tidak boleh diganggu, dan "boleh dituntut, diterima, dan disebarkan melalui sebarang bentuk media dan tanpa mengira sempadan".16 ICCPR pula boleh dianggap sebagai huraian kepada UDHR yang bersifat umum. Menurut Perkara 19 ICCPR, hak kebebasan bersuara dijamin namun boleh disekat melalui undang-undang dengan tujuan untuk: (i) menjaga hak dan reputasi orang lain; dan ii) melindungi keselamatan negara dan ketenteraman awam. ${ }^{17}$ Walau bagaimanapun, sekatan yang dibolehkan melalui ICCPR haruslah ditafsirkan secara berhati-hati. Sekatan tersebut mestilah digubal melalui undang-undang, dibuat atas

16 Selain daripada Perkara 19 UDHR, Farid Sufian dan Fatai Sambo berpendapat bahawa terdapat perkara-perkara lain di bawah UDHR yang berkaitan dengan jaminan terhadap hak kebebasan bersuara. Hal ini termasuklah Perkara 16, Perkara 17, dan Perkara 18. Sila rujuk Abdul Fatai Sambo and Farid Sufian Shuaib. (2012). The Rights and Duties of Journalists in a Constitutional Democracy: An Analytical Exposition. Australian Journal of Basic and Applied Sciences, 6(11), 145-52. being the watchdog of the society, seem indispensable in a constitutional democracy. Yet, collision course between the journalists and the law enforcement agents appears unavoidable. Sometimes, journalists allege violence and intimidation on the part of the law enforcement agents. The law enforcement agents also allege that the journalists do not keep within their limits. In a constitutional democracy, certain rights and duties are expected of the journalists. This paper therefore analyses the rights and duties of journalists in this regard. To achieve this, it uses a number of international human rights instruments; constitutional provisions and case laws to make the legal analysis. It further discusses the independence of journalists and the protection of journalistic sources in a constitutional democracy. It finds that these rights are not adequately appreciated by many stakeholders and that the duties are sometimes neglected even by the journalists themselves. It further finds that these rights (together with its limitations.

17 ICCPR, Perkara 19(3) 
dasar kepentingan yang sah, dan hanya dikenakan bagi memenuhi sebabsebab yang digariskan di bawah Perkara 19(3) ICCPR. ${ }^{18}$

Secara amnya, hak kebebasan bersuara di Malaysia dijamin oleh Perkara 10(1)(a) Perlembagaan Persekutuan. Namun demikian, Perlembagaan Persekutuan juga memberikan kuasa kepada Parlimen untuk menggubal undang-undang yang boleh menyekat kebebasan bersuara sekiranya memenuhi alasan yang dibenarkan dalam Perlembagaan seperti melindungi ketenteraman awam dan moral. ${ }^{19}$ Menurut Shad Saleem Faruqi, melalui peruntukan ini, kebebasan bersuara boleh disekat, dan sekatan ini perlu bagi mengelakkan kebebasan tersebut disalah guna bagi tujuan yang tidak sah. ${ }^{20}$ Sehingga 14 Januari 2021, sebanyak 275 kertas siasatan berhubung dengan laporan palsu COVID-19 telah dibuka oleh Polis Diraja Malaysia (PDRM) serta Suruhanjaya Komunikasi dan Multimedia Malaysia (SKMM). Daripada jumlah tersebut, 138 kes masih dalam siasatan, manakala 35 kes telah didakwa di mahkamah, dan 21 kes daripadanya telah didapati bersalah. ${ }^{21}$ Oleh yang demikian, Parlimen telah menggubal perundangan yang bertujuan menyekat penyebaran berita palsu secara langsung ataupun tidak langsung, termasuklah informasi palsu yang berkaitan dengan COVID-19. Bahagian seterusnya akan mengupas isu kerangka perundangan ini dengan lebih lanjut.

\section{MENANGANI INFODEMIK DARI SUDUT PERUNDANGAN SEDIA ADA}

Secara amnya, terdapat banyak undang-undang yang digunakan bagi menyekat kebebasan bersuara digubal dan dikuatkuasakan, termasuklah bagi tujuan untuk mengawal maklumat berita palsu.

Antara undang-undang khas yang digubal bagi mengekang penyebaran dan penghasilan berita palsu termasuklah seksyen 8A Akta Mesin Cetak

18 Sonia Randhawa, Pauline Puah, \& Susan Loone. (2005). Freedom of expression and the media. Baseline Studies on Seven Southeast Asian Countries. London. http:// medcontent.metapress.com/index/A65RM03P4874243N.pdf.

19 Sila rujuk Perkara 10(2), Perkara 10(3), dan Perkara 10(4) Perlembagaan Persekutuan.

20 Shad Saleem Faruqi. (2008). Document of destiny: The Constitution of the Federation of Malaysia. 1st Edition. Star Publications (Malaysia) Bhd,153,282.

21 Manzor Zulkifli. (2021). 275 kertas siasatan berita palsu COVID-19. Kosmo! https:// www.kosmo.com.my/2021/01/14/275-kertas-siasatan-berita-palsu-covid-19/. 
dan Penerbitan 1984. Digubal pada tahun 1987, seksyen ini melarang hasil penerbitan berita palsu yang dihasilkan dengan niat jahat. Maksud "niat jahat" yang dinyatakan di bawah seksyen 8A(1) dihuraikan di bawah seksyen 8A(2). "Niat jahat" ditafsirkan sebagai kegagalan tertuduh "mengambil langkah yang munasabah untuk menentusahkan kebenaran berita itu". Tafsiran yang lebih lengkap dibuat di mahkamah rayuan dalam kes Lim Guan Eng v PP apabila mahkamah mentafsirkan bahawa "berita itu adalah tidak benar sekiranya secara faktanya palsu diluar keraguan yang munasabah". ${ }^{22}$ Seksyen 8A pernah dicabar dalam kes Public Prosecutor v Pung Chen Choon, apabila tertuduh mendakwa bahawa peruntukan ini bertentangan dengan jaminan hak kebebasan bersuara seperti yang termaktub di bawah Perkara 10 Perlembagaan Persekutuan. Walau bagaimanapun, mahkamah menegaskan bahawa seksyen 8A (2) tidaklah digubal bagi menyekat hak kebebasan akhbar dan bersuara secara langsung atau mahupun tidak langsung, namun seksyen ini digubal bagi memastikan kebebasan yang dijamin di bawah Perlembagaan Persekutuan tidak dicabuli ataupun dieksploitasi atas nama kebebasan. ${ }^{23}$

Pada masa yang sama undang-undang antifitnah turut boleh digunakan secara tidak langsung bagi mengekang penghasilan dan penularan berita palsu. Secara amnya, terdapat dua jenis tindakan terhadap fitnah yang boleh dilakukan, iaitu menerusi tuntutan jenayah dan juga tuntutan sivil. Seksyen 499 ke 502 Kanun Keseksaan melarang fitnah jenayah. Tindakan diambil oleh pihak pendakwa raya yang mewakili kepentingan awam. Namun begitu, pada masa yang sama tuntutan sivil juga boleh dilakukan di bawah Akta Fitnah 1957. Secara khusus, kes Ayob Saud v. TS Sambanthamurthi, Mohamed Dzaiddin J. meletakkan unsur-unsur yang diperlukan untuk mewujudkan fitnah atau fitnah seperti yang termaktub dalam Akta Fitnah 1957, plaintif mesti membuktikan tiga elemen: (1) kata-kata itu mesti memfitnah; (2) kata-kata mesti merujuk plaintif; dan (3) perkataan itu mesti diterbitkan. ${ }^{24}$

Akta Hasutan 1948 ialah undang-undang yang melarang penerbitan yang dianggap menghasut. Perbuatan itu pada awalnya digubal oleh pihak berkuasa penjajah British Malaya pada tahun 1948. Perbuatan itu

22 Lim Guan Eng v PP [1988] 3 MLJ 14 (COA)

23 Mohd Safar Hashim. (2002). Mengenali Undang-Undang Media dan Siber. 1st Edition. Utusan Publication \& Distributors Sdn Bhd, 13.

24 [1989] 1 CLJ 152 at 155; [1989] 1 CLJ (Rep) 321. 
melarang pertuturan dengan kecenderungan menghasut, termasuk yang akan menimbulkan kebencian atau penghinaan atau membangkitkan rasa tidak puas hati terhadap pemerintah atau menimbulkan perasaan buruk dan permusuhan antara pelbagai kaum.

Maksud "kecenderungan menghasut" didefinisikan dalam seksyen 3 Akta Hasutan 1948. Secara dasarnya, "kecenderungan menghasut" serupa dengan definisi undang-undang biasa tentang hasutan, dengan pengubahsuaian mengikut keadaan setempat. Hal ini merangkumi perbuatan mempertikaikan bahagian-bahagian tertentu dalam Perlembagaan Malaysia, contohnya yang berkaitan dengan kontrak sosial Malaysia, Bahasa Malaysia sebagai bahasa rasmi, dan hak-hak istimewa untuk bumiputera. Seksyen 4 Akta Hasutan menetapkan bahawa sesiapa yang melakukan atau cuba melakukan, atau membuat persiapan untuk melakukan, atau bersekongkol dengan mana-mana orang untuk melakukan tindakan dengan kecenderungan menghasut, seperti mengucapkan katakata hasutan, atau mencetak, menerbitkan atau mengimport sastera hasutan, boleh didapati bersalah kerana melakukan hasutan. Memiliki penerbitan hasutan tanpa alasan yang sah juga merupakan suatu kesalahan di bawah peruntukan ini.

Dalam kes Muhammad Safwan bin Anang@Talibv Public Prosecutor and another appeal [2017] 1 MLJ 620, isu sama ada penyataan yang disinggung itu ada kecenderungan menghasut atau tidak merupakan suatu perkara yang harus dinilai melalui pengadilan secara objektif dengan mempertimbangkan makna semula jadi kata-kata, atau kata-kata dalam pernyataan yang digunakan. Untuk menjadikannya kenyataan yang menghasut, Mahkamah harus mendapati bahawa penyataan tersebut telah melintasi batasan komen politik yang boleh diterima oleh undangundang. ${ }^{25}$

Namun begitu, berdasarkan pemerhatian penulis, siasatan dan pendakwaan kes berkaitan dengan penyebaran berita palsu tentang pandemik COVID-19 mutakhir ini dibuat berdasarkan peruntukan seperti seksyen 505(b) Kanun Keseksaan dan seksyen 211 dan seksyen 233 Akta Komunikasi dan Multimedia 1998.

Seksyen 505(b) Kanun Keseksaan melarang perbuatan mendatangkan khianat awam dengan niat hendak menyebabkan ketakutan kepada orang awam. Seksyen ini turut diguna pakai bagi menyekat penyebaran berita

25 Rujuk juga Pendakwa Raya v Ooi Kee Saik \& Ors [1971] 2 MLJ 108. 
yang mampu menimbulkan ketakutan atau kegentaran kepada awam, yang juga memperuntukkan hukuman penjara sehingga dua tahun, atau denda, atau kedua-duanya sekali. Menurut sebuah badan bukan kerajaan (NGO) antarabangsa yang berpusat di United Kingdom, ARTICLE 19, seksyen 505(b) mempunyai potensi untuk disalah guna kerana memperuntukkan bidang kuasa yang amat luas kepada pihak berkuasa. ${ }^{26}$ Seksyen ini meletakkan liabiliti jenayah terhadap tafsiran penerima sesuatu maklumat atau informasi tersebut, bukannya kepada niat pembuat kenyataan. ${ }^{27}$ Seksyen ini dikhuatiri digunakan oleh sesetengah pihak untuk menangkis kritikan yang sah terhadap pihak berkuasa, dan juga digunakan bagi tujuan mengacau ganggu pengkritik tersebut dengan siasatan jenayah yang tidak perlu. ${ }^{28}$ Hal ini seterusnya memberikan implikasi yang besar terhadap kebebasan bersuara dan akhbar, terutamanya kepada petugas media yang berperanan sebagai "Estet Keempat" (the Fourth Estate) dalam demokrasi. Namun begitu, jika diteliti pada bahagian pengecualian peruntukan ini menyatakan bahawa seseorang tidak dianggap bersalah jika penerbitan atau pengedaran penyataan, khabar angin atau laporan tersebut dibuat dengan alasan yang munasabah dan dipercayai benar tanpa niat jenayah seperti yang disebutkan di atas. Dalam perkara ini, mahkamah perlu memainkan peranan untuk menilai fakta mengikut merit kes masingmasing demi memastikan undang-undang tidak disalah guna seperti yang didakwa oleh sesetengah pihak.

Selain itu, seksyen 211 dan seksyen 233 Akta Komunikasi dan Multimedia 1998 merupakan satu lagi akta yang digubal dengan niat untuk mengawal selia industri komunikasi dan multimedia di Malaysia. Seksyen 233 digunakan khusus untuk melarang penggunaan tidak wajar kemudahan rangkaian atau perkhidmatan rangkaian dengan niat untuk menyakitkan hati, menganiayai, mengugut atau mengganggu mana-mana orang melalui media sosial, portal berita yang menawarkan ruang komen, forum maya, serta aplikasi komunikasi seperti Whatsapp dan Telegram.

26 ARTICLE 19. (2020). Malaysia: Stop using repressive laws to counter misinformation about coronavirus. https://www.article19.org/resources/malaysia-stop-using-repressivelaws-to-counter-misinformation-about-coronavirus/.

27 Sila rujuk Seksyen 505(b) Kanun Keseksaan

28 Human Rights Watch. (2015). Creating a culture of fear: The criminilization of peaceful expression in Malaysia. https://www.hrw.org/sites/default/files/report_pdf/ malaysia1015_4up_0_0.pdf.:55 
Seksyen 211 pula digubal dengan tujuan untuk melarang pemberian atau penerbitan kandungan jelik secara umum yang boleh berlaku di laman sesawang, portal ataupun blog. ${ }^{29}$ Walaupun kedua-dua peruntukan mempunyai fokus yang berlainan, namun terdapat elemen larangan yang sama, iaitu menjadi satu kesalahan untuk membuat atau menyebarkan kandungan atas talian yang bersifat lucah, palsu, ataupun mengancam individu lain. ${ }^{30}$ Namun demikian, cabaran utama kedua-dua peruntukan ini adalah untuk mentafsirkan hal yang dimaksudkan "bersifat lucah, palsu, ataupun mengancam individu yang lain" yang hanya dinyatakan secara umum dalam peruntukan tersebut. ${ }^{31}$ Walaupun Kod Kandungan cuba menjelaskan yang dimaksudkan dengan "Kandungan Palsu", namun maksudnya masih lagi kabur. ${ }^{32} \mathrm{Hal}$ ini kerana, suatu kandungan ditafsirkan sebagai palsu sekiranya langkah-langkah wajar untuk menentukan kesahihannya tidak diambil atau tidak diterima sebelum kandungan itu disampaikan. ${ }^{33}$ Mahkamah sekali lagi dilihat begitu penting peranannya untuk memberikan tafsiran perundangan yang tepat untuk mengelakkan perundangan ini dilabel sebagai drakonian. Keabsahan seksyen 233 Akta Komunikasi dan Multimedia 1998 pernah dicabar di mahkamah melalui kes seperti Syarul Ema Rena binti Abu Samah v. Pendakwa Raya, apabila mahkamah memutuskan bahawa peruntukan tersebut tidaklah begitu kabur atau terlampau luas untuk ditafsirkan. Mahkamah juga berpandangan bahawa peruntukan tersebut bersesuaian dengan objektifAkta Komunikasi dan Multimedia 1998 serta berpelembagaan. ${ }^{34}$

Namun demikian, para pengkritik berpendapat bahawa penggunaan seksyen 505(b) Kanun Keseksaan serta seksyen 211 dan Seksyen 233 Akta

29 Mahyuddin Daud. (2019). Internet content regulation: Contemporary legal and regulatory issues in the changing digital landscape. IIUM Press, 305-307.

30 Seksyen 211 dan seksyen 233 Akta Komunikasi dan Multimedia 1998

31 Mahyuddin Daud. (2019). Internet content regulation: Contemporary legal and regulatory issues in the changing digital landscape.

32 Mahyuddin Daud \& Sonny Zulhuda. (2020). Regulating the Spread of False Content Online in Malaysia: Issues, Challenges and the Way Forward. International Journal of Business and Society, 21(S1), 32-48.

33 Sila lihat Kod Kandungan Komunikasi dan Multimedia Malaysia, Perkara 7.1.

34 Syarul Ema Rena binti Abu Samah v. Pendakwa Raya [2018] MLJ 1128. Lihat juga Nor Hisham bin Osman v Pendakwa Raya [2010] MLJU 1429 yang mana mahkamah turut mengesahkan Seksyen 233 tidaklah melanggar hak kebebasan bersuara seperti yang diperuntukkan dalam Perlembagaan Persekutuan. 
Komunikasi dan Multimedia 1998 untuk menangani infodemik haruslah hanya terhad pada kenyataan yang benar-benar mengundang bahaya yang nyata kepada masyarakat, bukannya bersifat palsu semata-mata. Penggunaan peruntukan yang disebutkan di atas juga boleh memberikan kesan yang besar terhadap proses semak dan imbang dalam negara terutamanya apabila melibatkan para wartawan. ${ }^{35}$ Pendekatan undangundang juga dilihat lebih bersifat menghukum daripada mendidik serta kurang memberikan kesan jangka panjang bagi tujuan meningkatkan etika sosial dan juga kewartawanan. ${ }^{36}$ Keadaan ini juga menunjukkan keperluan untuk sebuah badan pengawalan kendiri seperti Majlis Akhbar atau Majlis Media, yang bebas dan telus diwujudkan bagi mengelakkan insiden salah lapor dalam kalangan pengamal media. ${ }^{37}$ Badan ini seterusnya berperanan untuk memastikan bahawa etika asas kewartawanan dipatuhi oleh pengamal media, dan mempunyai kuasa

35 Sebagai contoh, seorang tokoh dunia kewartawanan, Wan Noor Hayati Alias telah dituduh di bawah seksyen 505(b) Kanun Keseksaan berturutan dengan perkongsian beliau mengenai COVID-19 di laman Facebook. Pertuduhan yang dibuat terhadap Hayati telah menimbulkan kegusaran banyak pihak termasuklah Kesatuan Kebangsaan Wartawan Semenanjung Malaysia (NUJM), yang mendakwa bahasa tindakan menyekat kebebasan wartawan untuk menyuarakan pendapat dilihat sebagai "mengancam demokrasi di mata rakyat serta masyarakat antarabangsa". Lihat International Federation of Journalists, "Malaysia: Journalist Charged for Coronavirus Facebook Posts," International Federation of Journalists, 2020, https://www.ifj.org/media-centre/news/detail/category/pressreleases/article/malaysia-journalist-charged-for-coronavirus-facebook-posts.html.The Star, "Group Urges Govt to Stop Using Criminal Proceedings Against Covid-19," The Star Online, 2020, https://www.thestar.com.my/news/nation/2020/03/24/group-urgesgovt-to-stop-using-criminal-proceedings-against-covid-19-misinformation.

36 Harris Zainul. (2020). Media freedom and fake news during the time of COVID-19. Institute of Strategic and International Studies (ISIS) Malaysia. https://www.isis.org. my/2020/04/15/media-freedom-and-fake-news-during-the-time-of-covid-19/.

37 Zainul, "Malaysia's Infodemic and Policy Response." 
untuk memberikan peringatan kepada pengamal media yang gagal mematuhi etika kewartawanan tersebut. ${ }^{38}$

Ordinan Darurat (Kuasa-Kuasa Perlu) (No.2) 2021 merupakan Ordinan yang diumumkan oleh YDPA menurut Artikel 150 Perlembagaan Persekutuan. Ordinan ini digubal kerana wujudnya keadaan darurat yang mengancam keselamatan, kehidupan ekonomi dan ketenteraman awam Persekutuan yang berpunca daripada wabak COVID-19. Ordinan ini memberikan tumpuan pada pengawalseliaan peraturan berita palsu dan berkuat kuasa pada12 Mac 2021 sehingga darurat dibubarkan oleh Yang Di-Pertuan Agong kelak. Secara asasnya, Ordinan ini melarang untuk mengadakan, menawarkan dan menerbitkan berita tidak benar. Setakat Tarikh kertas ini ditulis, belum ada penghakiman di bawah Ordinan ini yang telah selesai.

38 Farid Sufian Shuaib and Hafidz Hakimi Haron, "The Continuing Saga of the Proposed Malaysian Press Council: A Boone or Bane? [2019] 4 MLJ Cxxvii," Malayan Law Journal 4 (2019): cxxvii; Zainul, "Malaysia's Infodemic and Policy Response"; Raphael Cohen-Almagor, "Press Self-Regulation in Britain: A Critique," Science and Engineering Ethics, no. January 2014 (2014): 159-81, https://doi.org/10.1007/ s11948-014-9538-8.\{“id":’ITEM-2”,"itemData": ‘“author”:[\{“dropping-particle”:’”,", family":"Zainul",,"given":’Harris","non-dropping-particle":,",,"parse-names":false,"s-

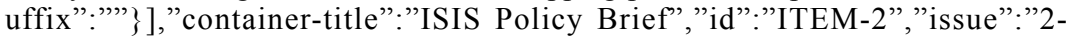
20","issued": \{“date-parts":[[“2020"]]\},"page":"1-4","title":"Malaysia's Infodemic and Policy Response","type":"article-journal"\},"uris":["http://www.mendeley. com/documents/?uuid=5b3af054-4627-4f38-9bb2-17311bf827de"]\}, “"id":"ITEM3","itemData": :“DOI":"10.1007/s11948-014-9538-8",’ISSN":"13533452","PMID ":"24682725","abstract":"This article reviews the history of press self-regulation in Britain, from the 1947 Ross Commission to the 2012 Leveson Inquiry Commission. It considers the history of the Press Council and the Press Complaints Commission, analysing the ways they developed, their work, and how they have reached their current non-status. It is argued that the existing situation in Britain is far from satisfactory, and that the press should advance more elaborate mechanisms of selfcontrol, establishing a new regulatory body called the Public and Press Council that will be anchored in law, empowering the new regulator with greater and unprecedented authority, and equipping it with substantive sanctioning abilities. The Public and Press Council should be independent and effective, with transparent policies, processes and responsibilities. Its adjudication should be made in accordance with a written, detailed Code of Practice."," author":[\{“dropping-particle":",,"family":"CohenAlmagor,,"given":’Raphael","non-dropping-particle":,",,"parse-names":false,"suffix":,'" \}],"container-title":’'Science and Engineering Ethics","'id":’ITEM-3","'issue":’January 2014","issued": \{“date-parts":[[“2014”]]\},"page":”159-181",,title":’Press SelfRegulation in Britain: A Critique","type":"article-journal"\},"uris":[“http://www. mendeley.com/documents/?uuid=1bf8cb3b-b924-4a7e-aef1-17049f5eb6a3"]\}],"me ndeley": ‘ "formattedCitation":'Farid Sufian Shuaib and Hafidz Hakimi Haron, "The Continuing Saga of the Proposed Malaysian Press Council: A Boone or Bane? [2019] 4 MLJ Cxxvii," <i>Malayan Law Journal $<$ i $>4$ (2019 


\section{MENGAPA “MAJLIS AKHBAR", BUKAN "MAJLIS MEDIA"?}

Mungkin ada yang hairan mengapa penulis memilih untuk menggunakan terma "Majlis Akhbar" bukannya istilah yang lebih popular iaitu "Majlis Media" sebagai sebahagian daripada tajuk artikel ini. Secara asasnya, ada yang berpendapat bahawa istilah "Majlis Akhbar" hanyalah sebuah terminologi dan boleh datang dalam bentuk istilah atau nama yang lain. ${ }^{39}$ Oleh yang demikian, ada yang mengatakan bahawa peristilahan sama ada badan tersebut dianggap sebagai "Majlis Akhbar" mahupun "Majlis Media" adalah tidak begitu penting. Tumpuan utama haruslah diberikan kepada fungsinya dalam mengawal selia industri media dan akhbar, bukannya peristilahan. ${ }^{40}$ Namun demikian, penulis berpendapat sebaliknya. Memilih istilah yang tepat bagi sesebuah badan pengawasan adalah penting kerana langkah ini dapat mencerminkan karakter, fungsi, skop dan bidang kuasa sesebuah badan tersebut. ${ }^{41}$

Secara amnya, Online Oxford Dictionary mentakrifkan "media" sebagai "komunikasi massa utama (penyiaran, penerbitan, dan internet) secara kolektif". MacMillan Dictionary mentafsirkan "media" sebagai kata jamak kepada "medium". Kamus Dewan pula mendefinisikan media sebagai "alat atau perantara komunikasi seperti radio, televisyen dan akhbar'. Oleh yang demikian, berdasarkan definisi yang diutarakan di atas, dapat ditanggapi bahawa "media" merujuk alat ataupun medium sesebuah maklumat ataupun berita boleh disebarkan. Oleh itu, secara istilahnya, Majlis Media merujuk sebuah badan yang mempunyai bidang kuasa terhadap semua jenis media, termasuklah penyiaran, radio, media bercetak, dan juga media atas talian. Perlu ditegaskan di sini bahawa, walaupun penggunaan perkataan "media" dan "akhbar" sering kali digunakan secara bertukar ganti, namun penulis berpendapat terdapat perbezaan ketara dari segi maksud istilah tersebut. Jika dilihat melalui definisi "Akhbar (Press)" oleh Online Oxford Dictionary merujuk "Akhbar-akhbar dan wartawan secara kolektif". Meriam-Webster

39 Ahmad Murad Merican, "Kematangan Wartawan, Majlis Akhbar," Utusan Malaysia, January 29, 2013, http://library.kehakiman.gov.my/digital/2013/JANUARI/UM/ UM_29_JAN_2013_003.pdf.

40 Mohd Safar Hasim and Ahmad Murad Merican, "The Formation of A Media Council: The Experience of Malaysia,” Jurnal Komunikasi, 2002.

41 Hafidz Hakimi Haron, Farid Sufian Shuaib, and Nadiah Arsat, "Some Like It Hoax : Lessons in Regulating Fake News in Malaysia," in International Conferance on Communication and Media (Sintok, 2020). 
Dictionary mendefinisikan akhbar sebagai "individu (seperti wartawan dan jurugambar) yang bekerja untuk akhbar, majalah, dan sebagainya". Dengan itu, berdasarkan definisi yang disebutkan di atas, perkataan "akhbar" lebih merujuk profesion untuk menyebarkan maklumat atau berita tersebut, seperti wartawan dan sebagainya. Definisi ini tidaklah terhad kepada medium atau alat sebaran maklumat atau berita sahaja. Hal ini bersesuaian dengan pendapat Murad Merican, iaitu istilah "akhbar" lebih merujuk profesion atau ahli media dan bukannya medium sebaran maklumat semata-mata. ${ }^{42}$

Oleh itu, penulis berpandangan bahawa nama yang tepat sesebuah badan tersebut seharusnya ialah "Majlis Akhbar" bukannya "Majlis Media", kerana objek utama kawal selia ialah profesion kewartawanan tersebut bukannya alat ataupun medium sesebuah penyampaian maklumat. Dalam pada itu, skop dan bidang kuasa majlis akhbar haruslah merentas semua medium, termasuklah media cetak, elektronik, penyiaran dan juga dalam talian, tetapi tidak termasuk media sosial. ${ }^{43}$ Dalam pada itu, skop Majlis Akhbar ini haruslah terhad kepada wartawan ataupun petugas media mahir atau profesional sahaja, bukannya mencakupi wartawan warga. Pada masa yang sama, penulis juga berpendapat bahawa dengan kepesatan perkembangan teknologi pada hari ini, istilah "akhbar" haruslah ditakrifkan secara lebih holistik dan tidak hanya terikat dengan takrifan kaku (rigid) seperti menerusi kaedah perundangan semata-mata. Oleh itu, definisi "akhbar" haruslah ditakrifkan secara bersesuaian dengan konteks masa dan teknologi.

42 Ahmad Murad Merican. (2018). Mentakrif semula kewartawanan. Sinar Harian. http://www.sinarharian.com.my/mobile/karya/pendapat/mentakrifsemula-kewartawanan-1.897915? fbclid=IwAR0IQh4OzYiLdiZ263 NBpV_ gGCxMDZRr8UrFOusBi3JdpAPq8fYg8bIg0p8.

43 Chamil Wariya. (2017). Isu-isu semasa kewartawanan dan media: Krisis dan strategi Malaysian Press Institute. 


\section{MENGURUS INFODEMIK: MENGIMBANGI HAK KEBEBASAN MEDIA DAN KEPENTINGAN UMUM MELALUI MAJLIS AKHBAR}

"Kita bukan sahaja sedang melawan epidemik, tetapi juga infodemik" - Dr Tedros Adhanom Ghebreyesus, Ketua Pengarah Pertubuhan Kesihatan Sedunia.

Hasrat untuk menubuhkan sebuah Majlis Media di Malaysia bukanlah sesuatu yang baharu, malah sudahpun diutarakan semenjak tahun 1974 lagi. Secara amnya, konsep Majlis Akhbar atau Majlis Media lahir di negara-negara Scandanivia. Majlis Akhbar pertama di dunia ditubuhkan di Sweden pada tahun 1916. ${ }^{45}$ Penubuhan Majlis Akhbar di Sweden pada ketika itu bertujuan untuk mengawal selia penguatkuasaan Kod Etika Kewartawanan dalam kalangan pengamal media di Sweden, pada masa yang sama juga berperanan sebagai forum untuk menyelesaikan apa-apa pertikaian antara pemilik industri media dan pengamal media. Peranan Majlis Akhbar Sweden kemudiannya diperluas dengan diberikan peranan sebagai penimbang tara antara pihak media dan pengguna media sekiranya terdapat apa-apa aduan dibuat daripada pihak pengguna. ${ }^{46}$ Keberkesanan Majlis Akhbar untuk melindungi kebebasan akhbar dan juga menguatkuasakan etika kewartawanan kepada pengamal media telah menjadi teladan kepada negara-negara yang lain. Hal ini dapat dilihat apabila negara-negara yang lain mula menubuhkan Majlis Akhbar mereka sendiri, termasuklah Finland (1968), Denmark (1964) dan United Kingdom (1953). ${ }^{47}$

Di Malaysia pula, idea penubuhan Majlis Akhbar atau Majlis Media lahir ketika Tun Razak memegang jawatan Perdana Menteri. Lanjutan

44 UNESCO, “UNESCO Welcomes Press Councils' Call for Professional Reporting on COVID-19 in South East Europe," UNESCO, 2020, https://en.unesco.org/news/ unesco-welcomes-press-councils-call-professional-reporting-covid-19-south-easteurope.

45 ara Fielden, "Regulating the Press: A Comparative Study of International Press Councils," 2012, http://www.theacademiclibrary.com/login_cat.asp?f ilename $=0745311989 \% 5 \mathrm{Cnhttp}: / / \mathrm{www}$. theacademiclibrary.com/login_cat. asp?filename $=0745311989 \&$ libcode $=$ PLC.91 IMPRESS.

46 Fielden.

47 Lara Fielden, "A Royal Charter for the Press: Lessons from Overseas," Journal of Media Law 5, no. 2 (2013): 172-88, https://doi.org/10.5235/17577632.5.2.172. 
idea ini, satu jawatankuasa peringkat tertinggi telah ditubuhkan bagi memperhalus cadangan tersebut, namun usaha ini gagal memberikan apaapa impak yang besar yang membawa kepada penubuhan Majlis Akhbar. ${ }^{48}$ Idea ini dihidupkan semula pada era 1980-an terutamanya berikutan dengan pengharaman beberapa akhbar oleh pihak kerajaan pada tahun 1987 dan juga pindaan terhadap Akta Mesin Cetak dan Penerbitan 1984 pada tahun yang sama. ${ }^{49}$ Namun begitu, sekali lagi cadangan tersebut gagal direalisasikan oleh sebab terdapat tentangan oleh pelbagai pihak. Cadangan penubuhan Majlis Media sekali lagi disuarakan pada awal tahun 2000, dan kemudiannya membawa kepada penyediaan Deraf Akta Penubuhan Majlis Media 2002. ${ }^{50}$ Draf ini telah dibuat hasil daripada usaha Institut Akhbar Malaysia (MPI) atas arahan Kerajaan pada ketika itu. Namun demikian, Draf Akta ini gagal dibentangkan di Parlimen oleh sebab terdapat tentangan dalam kalangan beberapa entiti pengamal media itu sendiri atas ketidaksetujuan berkenaan dengan struktur, kuasa, dan kebebasan Majlis Media tersebut. ${ }^{51}$ Cadangan terkemudian pula terbit daripada inisiatif kerajaan, iaitu pada 2005, 2007, 2008, 2010, 2011 dan $2013 .^{52}$ Namun begitu, seperti sebelumnya usaha ini mendapat tentangan daripada pihak pengamal media, kerana dikhuatiri penubuhan Majlis Media tersebut akan menjadi mekanisme pihak kerajaan untuk mengawal media dengan lebih ketat. ${ }^{53}$ Idea penubuhan Majlis Media hampir menjadi realiti pascapilihan raya umum ke-14 apabila Kerajaan Pakatan Harapan

48 Hasim \& Merican. (2002) The Formation of A Media Council: The Experience of Malaysia.

49 Chamil Wariya. (2017). Krisis dan Strategi : Cabaran Kewartawanan Dan Media Era Digital.

50 Untuk rujukan, sila lihat Jawatankuasa Petugas Mengkaji Cadangan Penubuhan Majlis Media Malaysia, "Cadangan Penubuhan Majlis Media Malaysia" (Kuala Lumpur, 2001), http://mpi.my/wp/wp-content/uploads/2019/05/Cadangan-Penubuhan-MajlisMedia-Malaysia.pdf.

51 Centre of Independent Journalism, "Media Council," CIJ, 2019, http://cijmalaysia. org/miniportal/2010/09/media-council/.

52 Sufian Shuaib and Hakimi Haron. The Continuing Saga of the Proposed Malaysian Press Council: A Boone or Bane? [2019] 4 MLJ Cxxvii."

53 Sufian Shuaib and Hakimi Haron; Hafidz Hakimi Haron. (2020). The Malaysian Press Council: Towards Striking a Balance Between Public Interest and Freedom of Press. (International Islamic University Malaysia, 240-245. 
yang baharu menjanjikan penubuhan Majlis Media sebagai sebahagian manifesto pilihan rayanya. ${ }^{54}$ Perkembangan ini telah membawa kepada pembentukan sebuah jawatankuasa khas yang dianggotai oleh pemain industri media cetak dan elektronik, serta Badan Bukan Kerajaan (NGO) pada tahun 2019.55 Terkini, dikhabarkan draf sebuah Akta bagi menubuhkan Majlis Media telah diserahkan kepada pihak berkaitan untuk dibentangkan di Parlimen. ${ }^{56}$ Namun sehingga Januari 2021, masih belum ada apa-apa perkembangan yang positif berkenaan dengan cadangan tersebut.

Secara asasnya, fungsi utama Majlis Akhbar adalah untuk membolehkan pihak industri mengawal selia media secara kendiri, sekali gus memberikan jaminan yang lebih baik terhadap kebebasan akhbar. ${ }^{57}$ Di sesetengah negara, seperti di India, Majlis Akhbar turut berperanan sebagai "jambatan" antara pihak kerajaan dan pengamal media dalam usaha menyelesaikan isu-isu yang berkaitan dengan kebebasan akhbar. ${ }^{58}$ Namun begitu, yang lebih penting, menurut Chamil Wariya, Majlis Akhbar juga berperanan untuk menyediakan dan menguatkuasakan etika kewartawanan yang tinggi berdasarkan prinsip etika kewartawanan yang sedia ada. ${ }^{59}$

Etika Kewartawanan merupakan tulang belakang sesebuah Majlis Akhbar atau Majlis Media. ${ }^{60}$ Secara amnya, menurut Itai Himelboim dan Yehiel Limor, Etika Kewartawanan diwujudkan bagi memaklumkan

54 Pakatan Harapan, Buku Harapan: Rebuilding Our Nation Fulfilling Our Hopes (Putrajaya: Pakatan Harapan, 2018), http://kempen.s3.amazonaws.com/manifesto/ Manifesto_text/Manifesto_PH_EN.pdf.

55 The Star, "M 'Sian Media Council : 17 Appointed as pro-Tem Committee Members," The Star, 2020, https://www.thestar.com.my/news/nation/2020/01/16/msian-mediacouncil-17-appointed-as-pro-tem-committee-members.

56 Bernama, "Proposed Media Council Draft Bill, Report Submitted to Ministry," Free Malaysia Today, 2020, https:/www.freemalaysiatoday.com/category/ nation/2020/09/05/proposed-media-council-draft-bill-report-submitted-to-ministry/.

57 Haron, "The Malaysian Press Council: Towards Striking a Balance Between Public Interest and Freedom of Press.", 527-528.

58 Haron.

59 Chamil Wariya, Ditemu bual penulis, Cyberjaya, Selangor, 17 October 2019.

60 Claude-Jean Bertrand, Media Ethics and Accountability Systems, 1st ed. (New York: Routledge, 2018), https://doi.org/https://doi.org/10.4324/9781351289641.,18. 
kepada masyarakat tentang etika industri akhbar. ${ }^{61}$ Pewujudan kod etika sebegini membantu untuk meningkatkan imej industri media sekali gus meningkatkan kepercayaan pengguna terhadap media tersebut. ${ }^{62}$ Di kebanyakan negara, Kod Etika Kewartawanan juga berperanan sebagai kompromi bagi mengelakkan intervensi undang-undang dibuat terhadap media oleh kerajaan yang kemudiannya boleh menyekat dan mengawal media secara lebih ketat. ${ }^{63}$ Pada masa yang sama, Kod Etika Kewartawanan boleh menjadi pelindung kepada pengamal media daripada ditindas oleh pemilik syarikat media. Menurut Bertrand, klausa yang berperanan untuk melindungi pengamal media boleh dimasukkan dalam sesebuah Kod Etika Kewartawanan tersebut. ${ }^{64}$ Secara amnya Kod Etika Kewartawanan mengandungi nilai asas etika kewartawanan seperti melaporkan berita yang tepat, telus dan benar, bersifat adil, berkecuali dan saksama dan melindungi hak asasi manusia. ${ }^{65}$ Oleh itu, penulis berpendapat bahawa kunci utama untuk mengawal infodemik adalah melalui pematuhan dalam kalangan warga media terhadap etika kewartawanan.

Penguatkuasaan etika kewartawanan akan membuka penyertaan massa dalam pentadbiran Majlis Akhbar secara langsung mahupun tidak langsung. ${ }^{66}$ Majlis Akhbar dapat berperanan sebagai badan rujukan alternatif kepada badan perundangan sedia ada, seperti mahkamah ataupun tribunal tuntutan yang berkaitan sekiranya terdapat prinsip etika kewartawanan yang dilanggar dan mendatangkan kesulitan kepada

61 Itai Himelboim \& Yehiel Limor. (2008). Media perception of freedom of the press: A comparative international analysis of 242 Codes of ethics. Journalism, 9(3), 235-65.

62 Himelboim and Limor (2008).

63 Claude-jean Bertrand. (1997). Quality control: Media ethics and accountability systems. Presses Universitaires de France, 18.

64 Bertrand (1997).

65 Peremobowei Akoje \& Mohd Helmi Abd Rahim. (2014). Development of Journalism Ethics: A Comparative Analysis of Codes of Ethics in Nigeria, United Kingdom, United States of America, India and Russia. Jurnal Komunikasi, Malaysian Journal of Communication, 30(2), 221-38, https://doi.org/10.17576/jkmjc-2014-3002-12.58 Haron.

66 Jalil Alil, Ditemu bual penulis, Shah Alam, Selangor, 4 October 2019. 
pengguna media. ${ }^{67}$ Melalui kaedah ini, proses mahkamah yang dilihat menekan media dapat dielakkan dan kebebasan media dapat dipelihara.68 Pada masa yang sama, langkah ini juga dapat membela nasib mangsa laporan pengamal media yang tidak bertanggungjawab tersebut melalui remedi seperti yang termaktub di bawah kuasa sesebuah Majlis Akhbar itu. ${ }^{69}$

Pertubuhan Kesihatan Sedunia (WHO) menggariskan lima strategi utama untuk mengawal infodemik. Pertamanya melalui analisis dan verifikasi bukti-bukti yang ada, keduanya memberikan penerangan terhadap maklumat yang bersifat saintifik, ketiga mengukur tahap infodemik tersebut, keempat mentaksirkan trend dan kesan infodemik tersebut, dan seterusnya kelima mengkoordinasi dan mengawal aliran teknologi maklumat. ${ }^{70}$ Dalam hal ini, penulis berpendapat bahawa Majlis Akhbar atau Majlis Media mampu menjadi pelaksana yang sesuai kepada strategi tersebut terutamanya bagi menangkis penularan dan penghasilan berita palsu dalam kalangan pengamal media itu sendiri. Sebagai contoh, Majlis Media atau Majlis Akhbar dapat berperanan sebagai badan pemantau dalam kalangan pengamal media bagi memastikan standard kewartawanan beretika dipatuhi. Hal ini sekali gus dapat mengelakkan penularan berita palsu. Usaha ini disokong oleh UNESCO menerusi satu kenyataan yang menyatakan bahawa pengukuhan akauntabiliti media dan kesedaran awam dapat membendung penularan maklumat yang tidak sahih. Menurut UNESCO, bagi mencapai matlamat ini, sokongan penuh harus diberikan kepada Majlis Akhbar dan Media bagi memperkukuh komitmen terhadap penguatkuasaan etika kewartawanan. ${ }^{71}$ Oleh itu, yang

67 Hafidz Hakimi Haron, Farid Sufian Shuaib \& Nadiah Arsat. (2020). Some Like It Hoax: Lessons in Regulating Fake News in Malaysia.

68 Farah Marshita Abdul Patah, Ditemu bual penulis, Bangsar, Selangor, 4 October 2019; Abdul Jalil Ali, Ditemu bual penulis, Shah Alam, Selangor, 4 October 2019.

69 ESCO, "UNESCO Welcomes Press Councils' Call for Professional Reporting on COVID-19 in South East Europe," UNESCO, 2020.

70 Viroj Tangcharoensathien et al., "Framework for Managing the COVID-19 Infodemic: Methods and Results of an Online, Crowdsourced Who Technical Consultation," Journal of Medical Internet Research 22, no. 6 (2020): 1-8, https://doi. org/10.2196/19659.

71 UNESCO, "UNESCO Welcomes Press Councils' Call for Professional Reporting on COVID-19 in South East Europe," 2020. 
berikut disertakan beberapa contoh pendekatan dan strategi yang diambil oleh Majlis Akhbar dan Media yang terpilih bagi menangani penghasilan dan penyebaran infodemik yang berkaitan dengan COVID-19:

\section{(a) Majlis Etika Media Macedonia Utara (CMEM)}

Menurut pemerhatian penulis, Majlis Etika Macedonia Utara dilihat antara majlis akhbar atau majlis media yang paling proaktif dalam usaha menghadapi cabaran etika mengurus maklumat yang berkaitan dengan pandemik COVID-19. Usaha ini disokong oleh satu kenyataan yang dikeluarkan oleh UNESCO yang mengiktiraf CMEM sebagai badan yang terawal mengeluarkan amaran kepada penggiat media khususnya di Macedonia Utara supaya mengambil sikap berhati-hati apabila memilih sumber maklumat mereka. ${ }^{72}$ Hal ini, menurut UNESCO, mampu mengelakkan penyebaran maklumat yang tidak sahih, sekali gus mengingatkan media terhadap tanggungjawab mereka agar melaporkan berita yang tepat kepada massa. ${ }^{73}$

Seperti negara lain di dunia, industri akhbar di Macedonia Utara juga menghadapi cabaran yang besar dalam hal melaporkan berita yang berkaitan dengan pandemik COVID-19. Laporan tidak sahih, masalah plagiat, kesensasian berita dan maklumat tidak tepat, adalah antara kesan liputan media susulan pandemik COVID-19. ${ }^{74}$ Menurut CMEM, permasalahan laporan palsu dilihat meruncing pada tempoh Februari ke Julai 2020, disebabkan pandemik COVID-19 serta pilihan raya umum. ${ }^{75}$ Oleh itu, CMEM menerima sebanyak 84 aduan berkaitan dengan berita palsu dalam tempoh Januari hingga Jun 2020, yang menyamai jumlah kes yang sama bagi keseluruhan pada tahun 2019. ${ }^{76}$ Dalam tempoh Mac hingga Ogos 2020, 70\% laporan yang diterima adalah tentang liputan yang berkaitan dengan COVID-19. ${ }^{77}$ Daripada jumlah itu, 46\% daripadanya

72 UNESCO.

73 UNESCO.

74 Marina Tuneva. (2020). The Critical Role of Press and Media Councils in Time of Covid-19 (Macedonia). https://en.unesco.org/sites/default/files/critical_role_press_ media_councils_covid19.pdf.

75 Tuneva (2020).

76 Tuneva (2020).

77 Tuneva (2020: 14) 
berkaitan dengan perlanggaran Artikel 1 Kod Wartawan Macedonia, iaitu yang bersangkutan dengan penerbitan tidak tepat serta kurangnya pengesahan (verifikasi) terhadap berita tersebut sebelum diterbitkan. ${ }^{78}$

Lanjutan daripada itu, pada Mac 2020 CMEM memulakan langkah untuk menerbitkan garis panduan bagi meningkatkan profesionalisme dalam kalangan pengamal media. Garis panduan ini dipanggil sebagai "Garis Panduan untuk Keselamatan dan Laporan Berhemah tentang Coronavirus". ${ }^{79}$ Garis panduan ini ialah manual tentang etika, profesionalisme dan kebertanggungjawaban kewartawanan tentang Coronavirus dalam era pandemik. Manual ini juga turut menyentuh langkah berjaga-jaga standard dalam penyediaan laporan, serta syor kepada petugas media di lapangan, juga garis panduan terhadap kerja penyuntingan. ${ }^{80}$ Antara syor yang disebut termasuklah: (1) petugas media haruslah sentiasa merujuk sumber maklumat rasmi, seperti laman Pertubuhan Kesihatan Sedunia (WHO), dan sebagainya; (2) menggunakan terminologi yang tepat; dan (3) mengelakkan diskriminasi sosial dan penstigmaan. ${ }^{81}$

\section{(b) Organisasi Standard Kewartawanan Bebas (IPSO)}

Organisasi Standard Kewartawanan Bebas (IPSO) merupakan sebuah badan bebas yang ditubuhkan bagi tujuan memantau etika dan tatatertib etika kewartawanan ahlinya yang terdiri daripada syarikat akhbar di United Kingdom. IPSO memulakan operasinya pada tahun 2014, susulan daripada pembubaran Suruhanjaya Aduan Akhbar (PCC) United Kingdom pada tahun yang sama. ${ }^{82}$ Seperti badan kawal selia etika kewartawanan

78 Tuneva. 8

79 Marina Tuneva, "Guidelines for Safe and Professional Reporting on the Coronavirus" (Skopje, 2020).

80 Tuneva, "The Critical Role of Press and Media Councils in Time of Covid-19.", 24.

81 Tuneva.

82 PCC dibubarkan oleh kerana ia berhadapan dengan pelbagai kritikan termasuklah kegagalan untuk menguatkuasakan etika kewartawanan kepada syarikat-syarikat akhbar. Suruhanjaya Leveson berpendapat bahawa penyeliaan kendiri terhadap akhbar di United Kingdom telah gagal, dan satu mekanisme pemantauan baharu perlu dibentuk bagi memantau etika kewartawanan di Britain. Sila rujuk Raphael CohenAlmagor, "Press Self-Regulation in Britain: A Critique," Science and Engineering 
yang lain, IPSO juga mempunyai Kod Etika kewartawanannya sendiri, yang dipanggil Kod Editor. Secara umumnya, Kod ini menggariskan beberapa perkara yang perlu dipatuhi ahlinya untuk membentuk tahap profesionalisme kewartawanan dan etika tertinggi. ${ }^{83}$ Antaranya termasuklah nilai-nilai kewartawanan sejagat seperti keperluan untuk melaporkan secara tepat dan telus, menghormati hak privasi, dan juga larangan terhadap kacau ganggu, dan banyak lagi. ${ }^{84}$ Perlanggaran terhadap Kod Editor memberikan kuasa kepada IPSO untuk mengenakan beberapa tindakan terhadap ahlinya, antaranya termasuklah mengarahkan supaya editor tersebut supaya berita tersebut dipadamkan, membuat pembetulan, melakukan permohonan maaf, mengenakan denda dan sebagainya. ${ }^{85}$

Untuk menghadapi cabaran pandemik dan infodemik, IPSO telah mengambil beberapa langkah proaktif bagi memastikan Kod Editor dipatuhi oleh ahlinya, sama ada daripada industri media cetak ataupun dalam talian yang melalui pemantauan lebih ketat daripada kebiasaannya. ${ }^{86}$ Hal ini termasuklah pemantauan yang lebih ketat terhadap berita palsu ataupun tidak tepat yang diterbitkan oleh media. Misalnya, berlaku dalam kes Imperial College London v. The Daily Telegraph ${ }^{87}$ apabila sebuah akhbar melaporkan bahawa individu daripada etnik minoriti di United Kingdom telah dilarang mengambil ujian percubaan klinikal vaksin COVID-19. Hal ini telah disangkal oleh pihak Imperial College dan menyifatkan laporan tersebut sebagai tidak tepat dan palsu. Dalam kes ini, IPSO telah mengeluarkan arahan supaya pembetulan yang sewajarnya dilakukan oleh akhbar tersebut terhadap tajuk artikel yang diterbitkan.

83 Independent Press Standards Organisation, "Editors' Code," Independent Press Standards Organisation, accessed September 1, 2019, https://www.ipso.co.uk/faqs/ editors-code/.

84 Tuneva. 14

85 “Arbitration,” IMPRESS, accessed September 20, 2019, https://impress.press/regulation/ arbitration.html.

86 IMPRESS, "IPSO Blog: Update on IPSO' s Covid-19 Reporting Monitor and Services," IMPRESS, 2020, https://www.ipso.co.uk/news-press-releases/blog/ipsoblog-update-on-ipso-s-covid-19-reporting-monitor-and-services/.

87 Resolution Statement - 28737-20 Imperial College London v The Daily Telegraph https://www.ipso.co.uk/rulings-and-resolution-statements/ruling/?id=28737-20 
(c) Pemantau Bebas untuk Akhbar (IMPRESS)

Selain IPSO, IMPRESS juga merupakan salah sebuah badan pemantau dan penguat kuasa etika kewartawanan di United Kingdom. IMPRESS ditubuhkan setahun selepas IPSO dibentuk pada tahun 2014. IMPRESS tertubuh atas persepsi bahawa IPSO ialah sebuah badan yang tidak sepenuhnya bebas dan terlampau berpihak kepada industri akhbar. ${ }^{88}$ Tidak seperti IPSO, IMPRESS merupakan badan pemantau etika kewartawanan pertama yang menerima pengiktirafan di bawah Piagam Diraja pada Mei 2015, dan diiktiraf secara rasmi sebagai pengawal selia akhbar pada tahun 2016.89

Seperti IPSO, IMPRESS juga memiliki Kod etika kewartawanannya sendiri, yang dinamakan sebagai "Kod Standard IMPRESS". ${ }^{90}$ Secara amnya, fasal di bawah Kod Standard IMPRESS hampir serupa dengan Kod Editor IPSO. Antaranya termasuklah tanggungjawab menyediakan laporan yang tepat, laporan tentang kanak-kanak, mengelakkan diskriminasi, kacau ganggu, dan privasi. Secara amnya, pematuhan terhadap Kod ini adalah secara sukarela. Sekiranya terdapat apa-apa pelanggaran terhadap Kod Standard, maka hukuman yang sesuai seperti pembetulan, atau permohonan maaf boleh dikenakan. Namun begitu, yang menariknya, tidak seperti IPSPO, IMPRESS mempunyai bidang kuasa untuk melaksanakan denda yang berat, iaitu mengenakan denda sebanyak $1 \%$ daripada perolehan yang berkaitan dengan penerbitan tersebut, dengan maksimum sebanyak £1 Juta.

Seperti IPSO, IMPRESS juga telah mengambil beberapa langkah untuk menyekat penyebaran berita palsu. Antaranya termasuklah memberikan peringatan bahawa penerbit berita wajib melaporkan apaapa perkara yang berkaitan dengan COVID-19 secara bertanggungjawab. Pada masa yang sama, IMPRESS turut mengeluarkan garis panduan

88 Emily Brothers et al. (2015). Ipso has failed to hold the press to account. The Guardian, September 7. https://www.theguardian.com/media/2015/sep/07/ipso-hasfailed-to-hold-the-press-to-account

89 Press Recognition Panel. (2016). PRP Board Decision in Respect of the Application for Recognition from IMPRESS: The Independent Monitor of the Press CIC 25 October. (London).

90 IMPRESS. (2019). Standards Code, IMPRESS. Diakses pada 20 Ogos 2019 daripada https://impress.press/standards/. 
tentang kaedah melaporkan berita berkaitan COVID 19. Antara inti pati garis panduan ini termasuklah, wartawan haruslah memastikan laporan tersebut tepat, mendapatkan maklumat daripada sumber yang sah, dan maklumat yang diterima haruslah mendapat pengesahan (verifikasi).

\section{KESIMPULAN}

Peranan Majlis Media atau Majlis Akhbar menjadi lebih penting terutamanya ketika situasi pandemik mutakhir ini. Sebagai badan kawal selia kendiri, majlis akhbar di serata dunia telah mengeluarkan beberapa garis panduan berkenaan dengan etika untuk melaporkan liputan berkaitan dengan COVID-19. Pada masa yang sama, Majlis Akhbar juga turut berperanan sebagai pelindung kepada khalayak media sekiranya mereka dianiayai oleh pengamal media yang tidak bertanggungjawab khususnya dalam konteks laporan berkaitan pandemik COVID-19. Dalam hal ini, masyarakat amnya yang terjejas disebabkan laporan tersebut boleh mengajukan aduan mereka kepada Majlis Akhbar dan tindakan tertentu boleh diambil terhadap pelaku kesalahan berkenaan berlandaskan bidang kuasa yang ada pada Majlis Akhbar tersebut. Dalam pada itu, Majlis Akhbar itu sendiri boleh mengambil peranan sebagai sebuah platform untuk menyebarkan berita dan maklumat yang sahih dan tepat kepada umum, sekali gus dapat menangkis penularan berita palsu. Melihat kepada kepantasan perkembangan teknologi maklumat pada hari ini, berita palsu, mahupun infodemik sentiasa menjadi duri dalam daging dalam masyarakat kita. Kaedah perundangan semata-mata dilihat kurang berkesan untuk menangani penyebaran berita palsu berkaitan dengan pandemik COVID-19. Regulasi terhadap kandungan dalam talian tidak boleh hanya bergantung pada kaedah perundangan, malah memerlukan sokongan seliaan kendiri. Oleh itu, penubuhan sebuah Majlis Akhbar di Malaysia haruslah disegerakan bagi memperkasakan kerangka perundangan dan mengawal selia kandungan sedia ada demi mengurangkan impak fenomena infodemik dan memerangi berita palsu yang tidak membawa sebarang manfaat kepada masyarakat, khususnya dalam kalangan penggiat media arus perdana. 


\section{RUJUKAN}

Abdul Fatai Sambo, \& Farid Sufian Shuaib. (2012). The rights and duties of journalists in a constitutional democracy: An analytical exposition. Australian Journal of Basic and Applied Sciences, 6(11): 145-52.

Ahmed, Sameera Tahira. (2020). Managing news overload (MNO): The COVID-19 infodemic. Information (Switzerland), 11(8). https://doi. org/10.3390/INFO11080375.

Akoje, Topic Peremobowei \& Mohd Helmi Abd Rahim. (2014). Development of Journalism Ethics: A Comparative Analysis of Codes of Ethics in Nigeria, United Kingdom, United States of America, India and Russia. Jurnal Komunikasi, Malaysian Journal of Communication, 30(2), 221-38. https:// doi.org/10.17576/jkmjc-2014-3002-12

“Arbitration.” IMPRESS. Accessed September 20, 2019. https://impress.press/ regulation/arbitration.html

ARTICLE 19. (2020). Malaysia: Stop Using Repressive Laws to Counter Misinformation about Coronavirus. Article 19. Diakses daripada https:// www.article19.org/resources/malaysia-stop-using-repressive-laws-tocounter-misinformation-about-coronavirus/

Bernama. (2020). Proposed Media Council Draft Bill, Report Submitted to Ministry. Free Malaysia Today. Diakses daripada https://www.freemalaysiatoday. com/category/nation/2020/09/05/proposed-media-council-draft-bill-reportsubmitted-to-ministry/

Bertrand, Claude-jean. (1997). Quality control: Media ethics and accountability systems. Presses Universitaires de France.

Bertrand, Claude-Jean. (2018). Media Ethics and Accountability Systems. 1st ed. Routledge. Diakses daripada https://doi.org/https://doi. org/10.4324/9781351289641.

Brothers, Emily, Douglas Wilson, Bob Littler, Reiner Luyken, Ahmed Mian, Robert Bray, \& Linda Pearson. (2015). Ipso Has Failed to Hold the Press to Account. The Guardian. September 7. Diakses daripada https://www. theguardian.com/media/2015/sep/07/ipso-has-failed-to-hold-the-press-toaccount

Centre of Independent Journalism. (2019). Media Council. CIJ. Diakses daripada http://cijmalaysia.org/miniportal/2010/09/media-council/

Chamil Wariya. (2017). Isu-isu semasa kewartawanan \& media: Krisis dan strategi. Malaysian Press Institute.

Chamil Wariya. (2017). Krisis dan strategi: Cabaran kewartawanan dan media era digital. Malaysian Press Institute.

Cohen-Almagor, Raphael. (2014). Press self-regulation in Britain: A critique. Science and Engineering Ethics 21(1), 159-81. https://doi.org/10.1007/ s11948-014-9538-8 
Emma Mohamad, Jen Sern Tham, Suffian Hadi Ayub, Mohammad Rezal Hamzah, Hasrul Hashim \& Arina Anis Azlan. (2020). Relationship between COVID-19 information sources and attitudes in battling the pandemic among the Malaysian public: Cross-sectional survey study. Journal of Medical Internet Research, 22(11), 1-13. https://doi.org/10.2196/23922

Farid Sufian Shuaib \& Hafidz Hakimi Haron. The continuing saga of the proposed Malaysian press council: A boone or bane? [2019] 4 MLJ Cxxvii. Malayan Law Journal 4 (2019): cxxvii.

Faruqi, Shad Saleem. (2008). Document of destiny: The Constitution of the Federation of Malaysia. 1st Editio. Star Publications (Malaysia) Bhd.

Fielden, Lara. (2013). A royal charter for the press: Lessons from oerseas. Journal of Media Law, 5(2), 172-88. https://doi.org/10.5235/17577632.5.2.172.

Fielden, Lara. (2012). Regulating the press: A comparative study of international press councils. Diakses daripada http://www.theacademiclibrary.com/login cat.asp?filename $=0745311989 \% 5 \mathrm{Cnhttp}: / /$ www.theacademiclibrary.com/ login_cat.asp?filename $=0745311989 \&$ libcode $=$ PLC

Hafidz Hakimi Haron. (2020). The Malaysian Press Council: Towards striking a balance between public interest and freedom of press. International Islamic University Malaysia.

Hafidz Hakimi Haron, Farid Sufian Shuaib \& Nadiah Arsat. (2020). Some like it hoax: Lessons in regulating fake news in Malaysia. International Conferance on Communication and Media, Sintok.

Harris Zainul. (2020). Malaysia's infodemic and policy response. ISIS Policy Brief, no. 2-20 (2020): 1-4. Diakses daripada https://www.isis.org.my/wpcontent/uploads/2020/06/POLICY-BRIEF_MALAYSIA-INFODEMICAND-POLICY-RESPONSE.pdf.

Harris Zainul. (2020). Strategic and international studies (ISIS) Malaysia. Diakses daripada https:/www.isis.org.my/2020/04/15/media-freedom-andfake-news-during-the-time-of-covid-19/

Himelboim, Itai, \& Yehiel Limor. (2008). Media perception of freedom of the press: A Ccomparative international analysis of 242 Codes of Ethics. Journalism, 9(3), 235-65.

Human Rights Watch. (2015). Creating a culture of fear: The criminilization of peaceful expression in Malaysia. Diakses daripada https:/www.hrw.org/ sites/default/files/report_pdf/malaysia1015_4up_0_0.pdf

IMPRESS. (2020). COVID-19. IMPRESS. https://www.impress.press/standards/ covid19.html\#note.

IMPRESS. (2020). IPSO Blog: Update on IPSO 's Covid-19 reporting monitor and services. IMPRESS. Diakses daripadahttps://www.ipso.co.uk/newspress-releases/blog/ipso-blog-update-on-ipso-s-covid-19-reporting-monitorand-services/ 
IMPRESS. Standards Code. IMPRESS. Diakses pada 20 Ogos 2019 daripada https://impress.press/standards/.

Independent Press Standards Organisation. Editors' Code. Independent Press Standards Organisation. Diakses pada 1 September 2019 daripada https:// www.ipso.co.uk/faqs/editors-code/.

International Federation of Journalists. (2020). Malaysia: Journalist charged for coronavirus Facebook posts. International Federation of Journalists.Diakses daripada https:/www.ifj.org/media-centre/news/detail/category/pressreleases/article/malaysia-journalist-charged-for-coronavirus-facebook-posts. html.

Jawatankuasa Petugas Mengkaji Cadangan Penubuhan Majlis Media Malaysia. (2001). Cadangan Penubuhan Majlis Media Malaysia. Diakses daripada http://mpi.my/wp/wp-content/uploads/2019/05/Cadangan-PenubuhanMajlis-Media-Malaysia.pdf.

Mahyuddin Daud. (2019). Internet content regulation: Contemporary legal and regulatory issues in the changing digital landscape. IIUM Press.

Mahyuddin Daud \& Sonny Zulhuda. (2020). Regulating the spread of false content online in Malaysia: Issues, challenges and the way forward. International Journal of Business and Society, 21(S1), 32-48.

Manzor Zulkifli. (2021). 275 Kertas siasatan berita palsu COVID-19. Kosmo! Diakses daripada https://www.kosmo.com.my/2021/01/14/275-kertassiasatan-berita-palsu-covid-19/

Merican, Ahmad Murad. (2013). Kematangan wartawan, Majlis Akhbar. Utusan Malaysia. January 29. Diakses daripada http://library.kehakiman.gov.my/ digital/2013/JANUARI/UM/UM_29_JAN_2013_003.pdf

Merican, Ahmad Murad. (2018). Mentakrif semula kewartawanan. Sinar Harian. Diakses daripada http:/www.sinarharian.com.my/mobile/karya/pendapat/ mentakrif-semula-kewartawanan-1.897915? fbclid=IwAR0IQh4OzYiLdiZ2 63NBpV_gGCxMDZRr8UrFOusBi3JdpAPq8fYg8bIg0p8

Mohd Safar Hashim. (2002). Mengenali undang-undang media dan siber. 1st Edition. Utusan Publication \& Distributors Sdn Bhd.

Mohd Safar Hashim \& Merican, Ahmad Murad. (2002). The formation of a media council: The experience of Malaysia. Jurnal Komunikasi.

Newman, Nic, Richard Fletcher, Anne Schulz, Simge And1 \& Rasmus Kleis Nielsen. (2020). Reuters Institute Digital News Report 2020. Diakses daripada https://reutersinstitute.politics.ox.ac.uk/sites/default/files/2020-06/ DNR_2020_FINAL.pdf.

Nordheim, Gerret von, Karin Boczek \& Lars Koppers. (2018). Sourcing the sources: An analysis of the use of Twitter and Facebook as a journalistic source over 10 years in The New York Times, The Guardian, and Süddeutsche 
Zeitung. Digital Journalism, 6(7), 807-28. Diakses daripada https://doi.org/ 10.1080/21670811.2018.1490658.

Pakatan Harapan. Buku harapan. (2018). Rebuilding our nation fulfilling our hopes. Pakatan Harapan. Diakses daripada http://kempen.s3.amazonaws. $\mathrm{com} /$ manifesto/Manifesto_text/Manifesto_PH_EN.pdf

Press Recognition Panel. (2016). PRP Board decision in respect of the application for recognition from IMPRESS: The Independent Monitor of the Press CIC 25 October 2016. London.

Radu, Roxana. (2020). Fighting the 'infodemic': Legal responses to COVID-19 disinformation. Social Media and Society, 6(3). https://doi. org/10.1177/2056305120948190

Randhawa, Sonia, Pauline Puah \& Susan Loone. (2005). Freedom of expression and the media. Baseline Studies on Seven Southeast Asian Countries. London. Diakses daripada http://medcontent.metapress.com/index/ A65RM03P4874243N.pdf.

Tangcharoensathien, Viroj, Neville Calleja, Tim Nguyen, Tina Purnat, Marcelo D’Agostino, Sebastian Garcia-Saiso \& Mark Landry. (2020). Framework for Managing the COVID-19 Infodemic: Methods and Results of an Online, Crowdsourced Who Technical Consultation. Journal of Medical Internet Research, 22(6), 1-8. https://doi.org/10.2196/19659

The Star. Group Urges Govt to Stop Using Criminal Proceedings Against Covid-19. The Star Online. (2020). Diakses daripada https://www.thestar. com.my/news/nation/2020/03/24/group-urges-govt-to-stop-using-criminalproceedings-against-covid-19-misinformation

The Star. (2020). M 'Sian Media Council : 17 Appointed as pro-Tem Committee Members. The Star. Diakses daripada https://www.thestar.com.my/ news/nation/2020/01/16/msian-media-council-17-appointed-as-pro-temcommittee-members

Tuneva, Marina. (2020). Guidelines for Safe and Professional Reporting on the Coronavirus. Skopje.

Tuneva, Marina. (2020). The critical role of press and media councils in time of COVID-19. Macedonia. Diakses daripada https://en.unesco.org/sites/default/ files/critical role press media councils covid19.pdf

UNESCO. (2020). UNESCO Welcomes Press Councils' Call for Professional Reporting on COVID-19 in South East Europe. UNESCO. Diakses daripada https://en.unesco.org/news/unesco-welcomes-press-councils-callprofessional-reporting-covid-19-south-east-europe

UNESCO. (2020). UNESCO Welcomes Press Councils' Call for Professional Reporting on COVID-19 in South East Europe. UNESCO. 
Wahl-Jorgensen, K. (2020). Advice for journalists covering Covid-19: Welsh NHS Confederation. IMPRESS. Diakses daripada http://orca.cf.ac.uk/id/ eprint/130629.

World Health Organization. (2020). Managing the COVID-19 Infodemic: Promoting healthy behaviours and mitigating the harm from misinformation and disinformation. World Health Organization. Diakses daripada https://www.who.int/news/item/23-09-2020-managing-the-covid-19infodemic-promoting-healthy-behaviours-and-mitigating-the-harm-frommisinformation-and-disinformation\%0Ahttps://www.who.int/news-room/ detail/23-09-2020-managing-the-covid-19-infodemic-promotin 